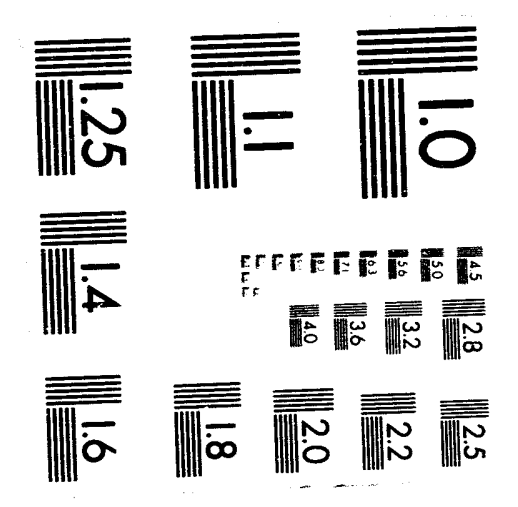



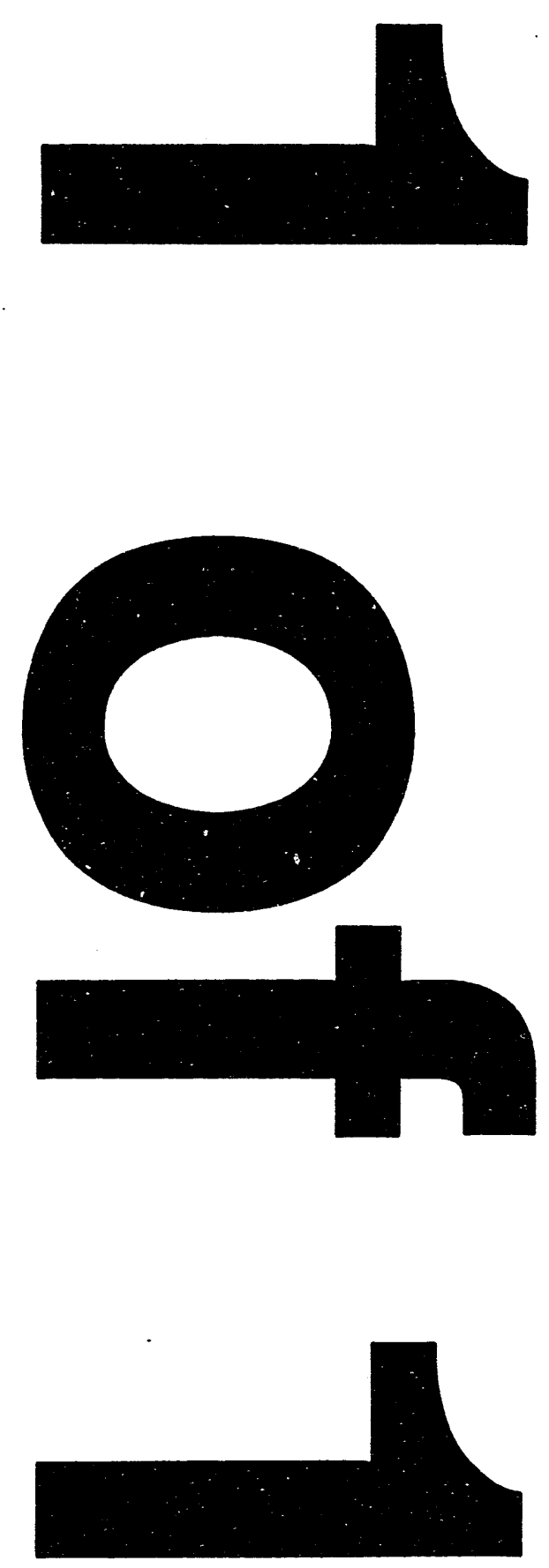
Cover Sheet for a Hanford

Historical Document

Released for Public Availability

Released 1994

Prepared for the U.S. Department of Energy under Contract DE-AC06-76RLO 1830

Pacific Northwest Laboratory Operated for the U.S. Department of Energy by Battelle Memorial Institute

Battelle 
This is a historical document that is being released for public availability. This was made from the best available copy. Neither the United States Government nor ariy agency thereof, nor Battelle Memorial Institute, nor any of their employees, makes any warranty, express or implied, or assumes any legal liability or responsibility for the accuracy, completeness, or usefulness of any information, apparatus, product, or process disclosed, or represents that its use would not infringe privately owned rights. The views and opinions of authors expressed herein do not necessarily state or reflect those of the United States Government or any agency thereof. 


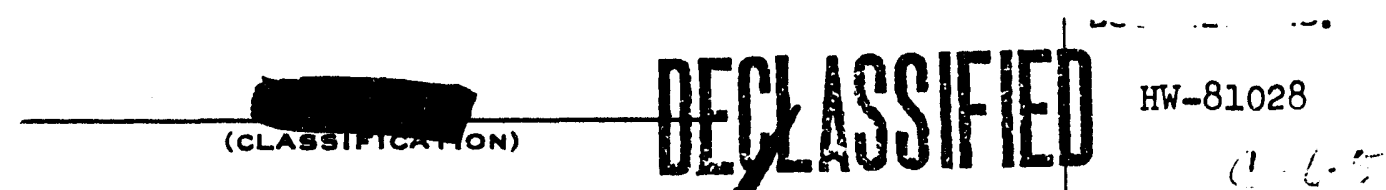 \\ GENERAL ELECTRIC \\ HANFORD ATOMIC PRODUCTB OPERATION - RICHLAND, WABHINGTON}

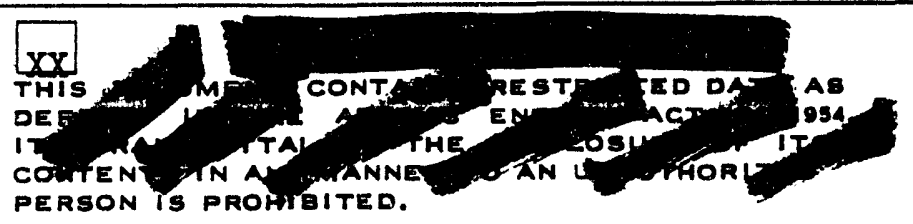

OTHER OFFICIAL CLASBIFIED INFORMATION

THIS MATERIAL CONTAIHB INFORMATION AFFECTINO THE NATIOMAL DEFENBE OF THE UNITED STATES WITHIN THE MEANING OF THE ESPIONAGE LAWS, TITLE 18, U. S.C., SECS. 793 AND 794, THE TRANBMISSION OR REVELATION OF WHICH IN ANY MANNER TO AN UNAUTHORIZED PERBON IS PROHIBITED GY LAW.

\section{TITLE}

TECHNICAL NOTE ON THE DETERMINATION OF

K-REACTOR LAST-DITCH COOLING ADEQUACY

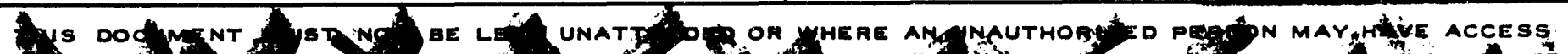

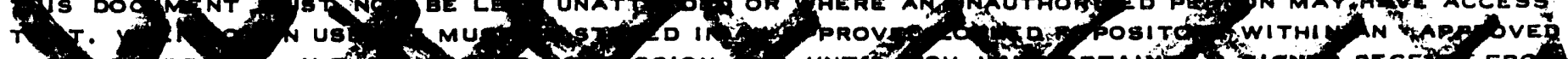

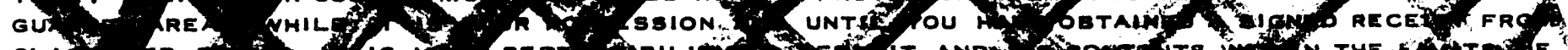

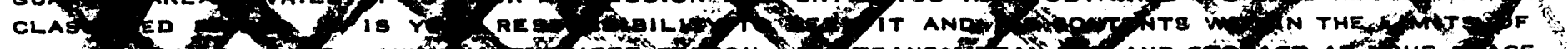

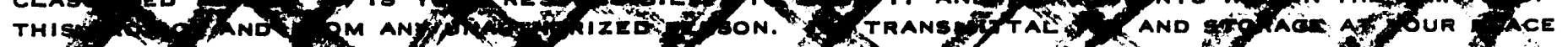

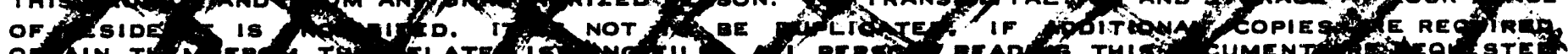

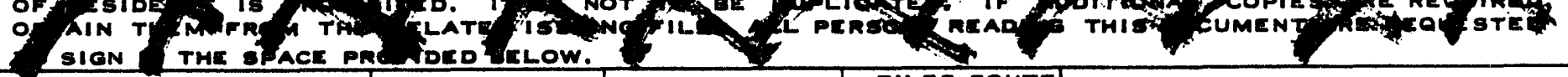
\begin{tabular}{l|l|} 
ROUTE TO: & PAYROLL NO. \\
\hline
\end{tabular} \begin{tabular}{|l|c|c|c|} 
LOCATION & FILESATOUTE & sjGNATURE AND DATE \\
\hline
\end{tabular}

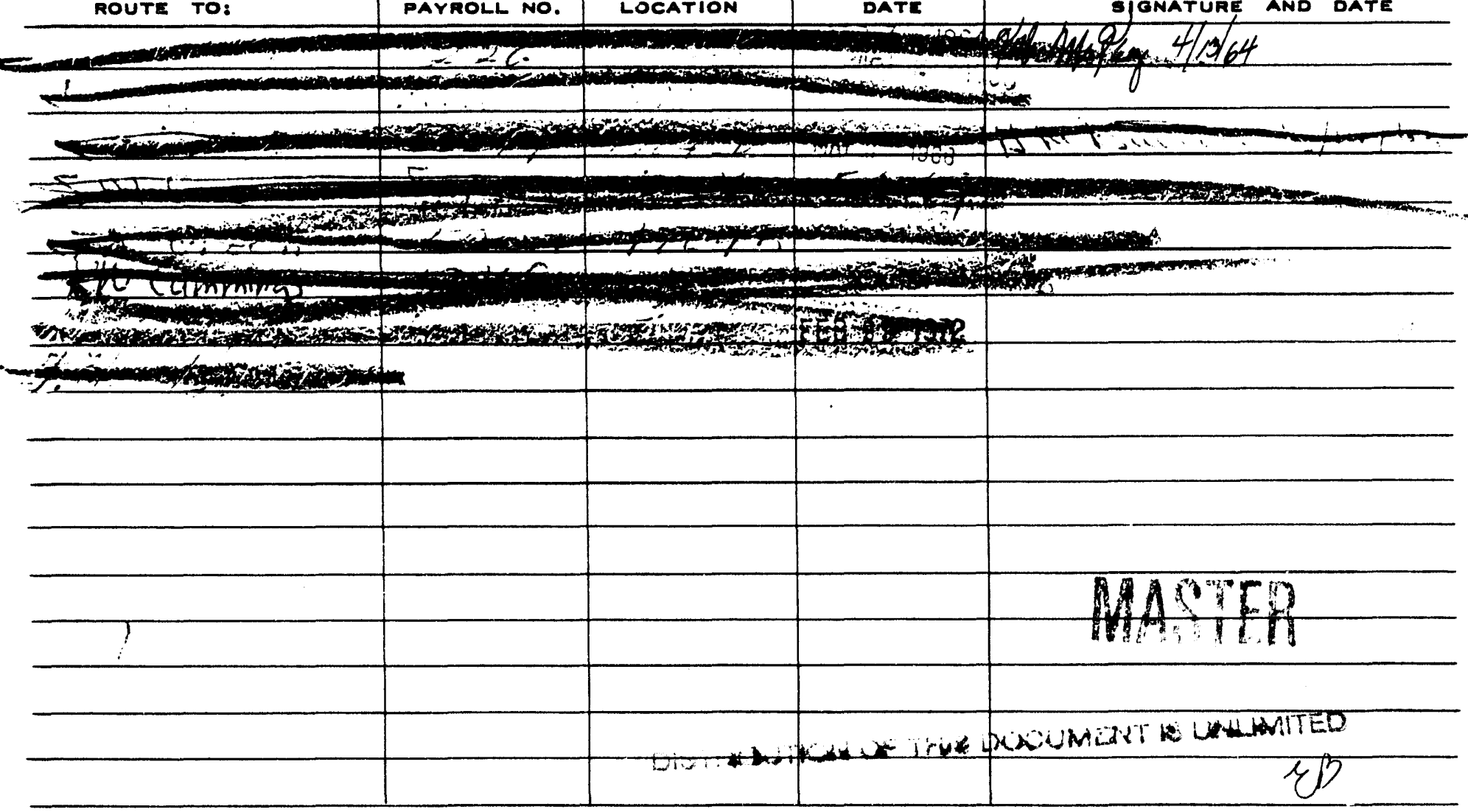




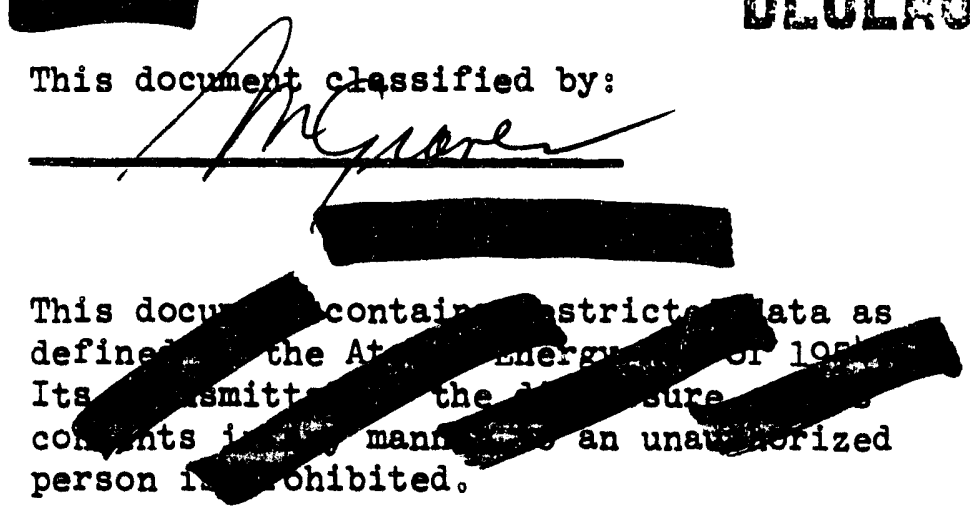

This document consists of pages. Copy No. 31 copies。 of

\title{
TECHNICAL NOTE ON THE DETERMINATION OF \\ K-REACTOR LAST-DITCH COOLING ADEQUACY
}

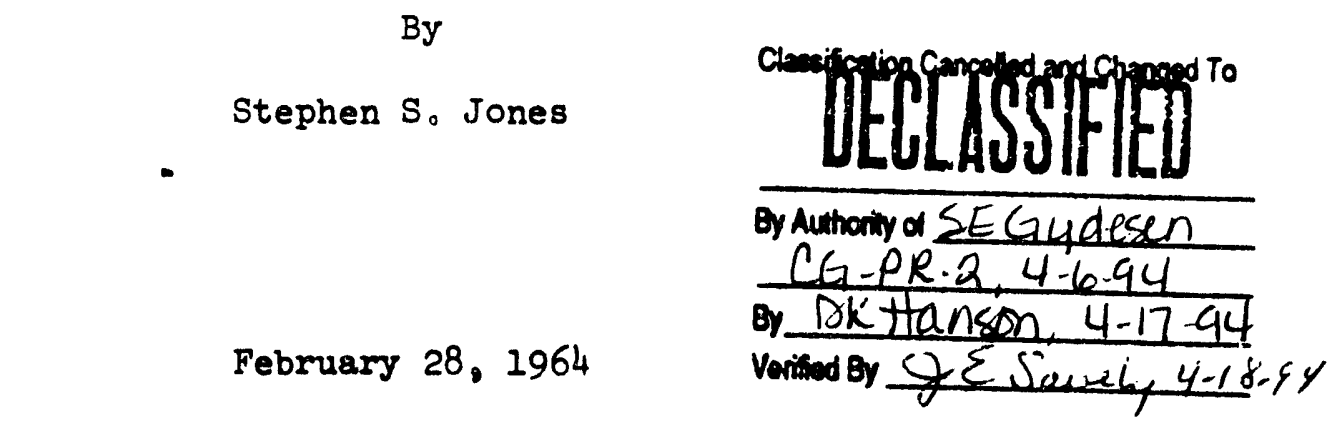

\section{HANFORd ATOMIC PRODUCTS OPERATION RICHLAND. WASHINGTON}

\begin{abstract}
NOTICE
This report was prepared for use within General Electric Company in the course of work under Atomic Energy Commission Contract AT(45-1) - 1350, and any views or opinions expressed in the report are those of the author only. This report is subject to revision upon collection of additional data.
\end{abstract}

\section{LEGAL NOTICE}

This report was prepared as an account of Government sponsored work. Neither the United States, nor the Commission, nor any person acting on behalf of the Commission:

A. Makes any warranty or representation, expressed or implied, with respect to the accuracy, completeness, or usefulness of the information contained in this report, or that the use of any information, apparatus, method, or process disclosed in this report may not infringe privately owned rights; or

B. Assumes ar $y$ liabilities with respect to the use of, or for damages resulting from the use of any information, apfuratus, method, or process disclosed in this report.

As used in the above, "person acting on behalf of the Commission" includes any employee or contractor of the Commission, or employee of such contractor, to the extent that such employee or con. tractor of the Commission, or employee of such contractor prepares, disseminates, or provides access to, any information pursuant to his employment or contract with the Commission, or his employment with such contractor. 


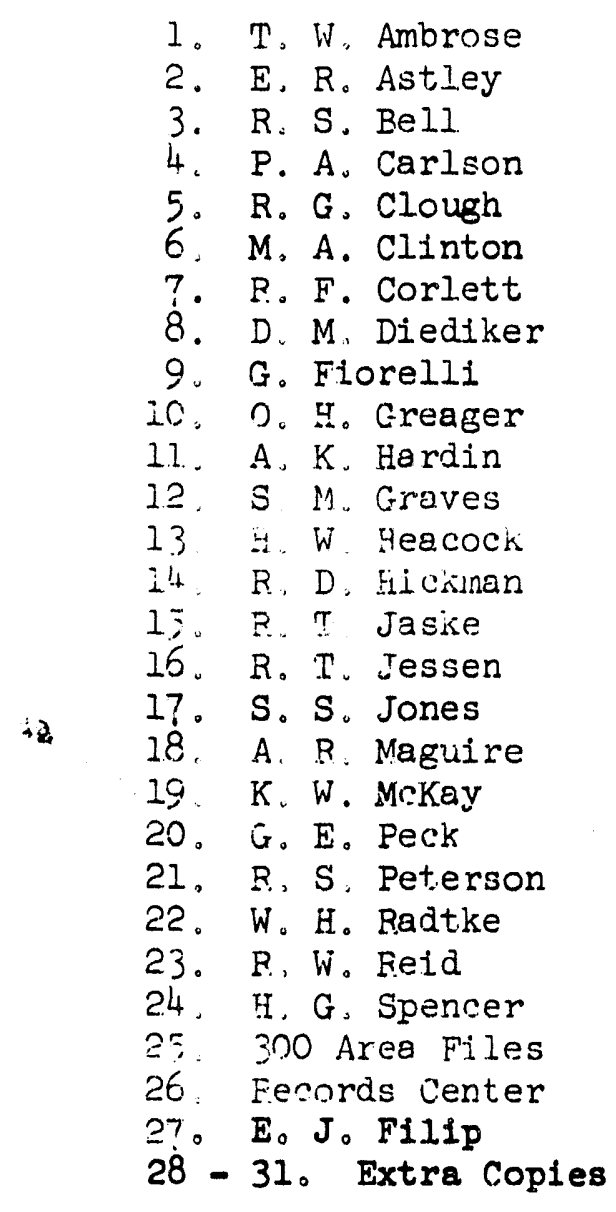




\section{TABIE OF CONTENTS}

Page

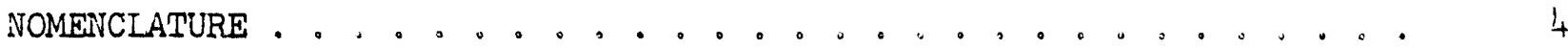

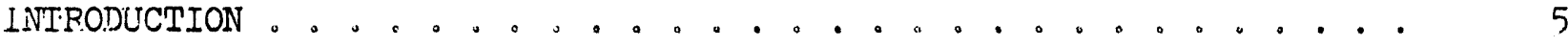

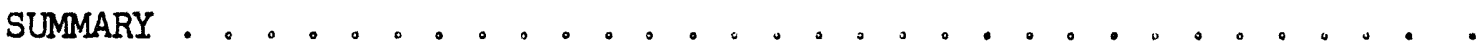

DISCIJSSION

1. General

2. Measured Last-Ditch Flow

Assured Last-Ditch Flow

4 Critical Flow Time and Heat Extraction Factor ${ }^{\circ} 0^{\circ} \cdot 0^{\circ} \cdot 0^{\circ} \cdot 0^{\circ} \cdot{ }^{\circ}$

5. Maximum Reactor Power Level for Adequate Last-Ditch Cooling".

6. Required Last-Ditch Cooling for Desired Reactor Power Level . .

?. Corrosion and Pumping Effects . . . . . . . . . . . . . .....

\section{LIST OF FIGURES}

Figure

1

2

3

4

5

$\varepsilon$

7

8
KE-Reactor Flow Vs.BORP

KW-Reactor Flow vs BORP

K-Rea tor Crosstie Line Corrosion Effect

Flow Temperature Factors

Low Flow Error Factors

Determination of Criticaj How and Time

Heat Extraction Fastor vs. Crutical Flow

KE, KMi Reactors Relative Heat Extraction Fequirements Following Reactor Scram

K-Reactor Emergency Flow Tube Outlet Temperature Limits 
NOMENCLATURE

${ }^{\pi} \mathrm{g}$ - Fraction of clean line flow to stricken reactor because of corrosjon.

$F_{\varepsilon}$ - Flattening efficiency, ratio of temperature rise in ten hottest standard tubes to the bulk effluent temperature rise.

$1+F_{G}-$ Low flow error factor, fractional increase in measured flow to allow for flow measurement errors.

$F_{S}$ - Fraction of measured flow that can be counted on during an emergency because of possible crossheader strainer plugging.

$F_{T}$ - A flow tenperature correction factor.

$\mathrm{f}_{G}$ - Fraction of fuil ievel flow at $\boldsymbol{\tau}$ seconds after a loss of pumping power

$f_{\boldsymbol{T}}$ - Fraction of original heat output, or heat extraction requirements at $\tau$ seconds after a loss of pumping power and reactor scram.

$G_{A}$ - Assured flow to stricken reactor - $1000 \mathrm{gpm}$.

$G_{M}$ - Measured flow to stricken reactor - $1000 \mathrm{gpm}$.

$G_{M}^{\prime}$ - Measured flow to aiding reactor (other K Reactor) - $1000 \mathrm{gpm}$.

op - Original full-level reactor flow - $1000 \mathrm{gpm}$.

$F_{B}$ - Reactor power level with adequate bulk effluent cooling after a BPA loss down to last-ditck backup - Mw.

$P_{0}$ - A reactor power level for which adequate last-dilon fiow should be determined - Mw.

$P_{t}$ - Reactor power level with adenuate process tube cooling after a BFA loss down to last-ditck. backup - $\mathrm{MW}$.

$T_{i}$ - Process water inlet temperature - ${ }^{\circ} \mathrm{C}$.

$\mathrm{T}_{i_{c}}$ - Crosstie water inlet temperature $-{ }^{\circ} \mathrm{C}$.

$X$ - Years since line sleaning.

$\propto$ - Lumped pumping flywheel decay parameter.

$\boldsymbol{I}$ - Time aiter reactor safety cod scram - seconds. 
TECHNICAL NOTE ON THE DETERMINATION OF K-REACTOR LAST-DITCH COOLING ADEQUACY

By: Stephen S。 Jones

\section{INTRODUCTION}

The Hanford reactors contain a very large inventory of fission products and it is very important that this inventory be contained. In recognition of this, rather stringent, reactor cooling requirements have been established for the Hanford reactors $(1,2)$ This includes the requirement of three independent cooling systems, including the system for full level operation. The second and last-ditch systems both are usable only after a reactor scram and take-over automatically from the flywheel decay of the process pumps.

In 1962, two projects were completed that affected the last-ditch cooling adequacy of the $K$ reactors, One project increased the reactor pumping capacity and, therefore; its power level; and the other considerably modified the emergency cooling sys..... Since this time, three tests have been conducted to determine this last-ditch cooing adequacy. In order to provide a uniform approach to this adequacy determination, the method employed by Reactor Engineering is presented herein.

\section{SUMMARY}

The report presents a method for determining the maximum reactor power level for which measured last-ditch flows will provide adequate emergency cooling. A number of pertinent charts are included. A method is also presented for determining the last-ditch flow that should be measured during a test for any desired level of remel reactor operation.

\section{DISCUSSION}

i. General

When pumping power is lost to the primary process pumps supplying the reactor sooling, the flow decays down to an emergen:y fiow provided by low-lift secondary pumps or by a tertiary pumping system. The process flow decays immedia:ely along a curve determined by the pump flywheel inertia and speed and the reator resistance characteristics. At the same time, this loss of power causes a scram of the vertical safety rods and after an initial delay of one to throe seconds, the reactor power level decays more rapidly than the f'lywheel decay of the reactor flow. It is expected that two to four of the low-lil't pumps will continue full level pumping and will take jver automatically from the flywheel decay of the high-ilft pumps within 40 to 60 seconds. There is a $r$ emote chance, however, that this secondary system may fail to respond to the power fallure of the high-lift pumps and that the reactor cooling must be provided by the third pumping system.

At this point the flywheel decay f'low is tapering off towards zero, while the reactor heat extraction requirements are leveling off to that produced by

- Present expectation is two low lifte plus the st vesign change \#lie, it will be four low lifts. 
radioactive decay of the fission products and the graphite sensible heat. Consequently, if this tertiary or last-ditch supply is too late or too littis excessive outlet temperatures will be obtained with the possibility of tube vapor lock and fuel burnout resulting. It should be noted, that under these assumed emergency conditions the front riser pressures during last-ditch cooling are very low and cannot be readily increased. Therefore, any filow reduction sufficient to cause tube bolling and vapor lock can result in no flow for perhaps several hours, with the probability of severe fuel damage. Theref'cre, it is important to have sufficient last-ditch cooling to avoid even temporary boiling.

This third coolant system for the $K$ Reactors consists of an independent dieselpowered pumping station located between the two reactor areas. The pump station is sized to supply either reactor with required emergency coolant flows upon demand but not both reactors simultaneously. The reactor win in requires the last-ditsh soolant is selected automatically by a hydralic balonce between the two reactors It is assumed that sne reactor wili retain ite secondar; system consisting of two low-lift pumps and tile steam turbine pump, intzh hes the capacity of a low lift. ihe back pressure estabilished at this nonstricken reactor tnen lorces the majority of the diesel pump output to" the reactor with no other source of coolant supply. This system is descrioed in detail in $\mathrm{BW}-74095$ vol3, pages $46-49,(3)$

Thie purpose of the last-ditch coolant svstem is to provide emergercy reactor coolant flow to one stricken $K$ Reactor should, foll jwist a ioce! is plant.wide loss of electrical power, the steam-powered secondary cooiant system isil to provide adequate reactor cooling. During the power-loss flow transient the reastor coclant flow decreases at a rate determined by the coast-down of the primary coolant pumps until, if the secondary coolant system does not respond, the water pressure in the reactor inlet piping reaches a vaiue equivaient to the pressure output of the accelerated diesel-driven, iast-ditch pumfe At tris point, the chech valve opens in the bigh pressire crosstie line and last. ditch fiow is supplied to the stricken reactor.

2. Measured Reactor Last-Ditch Flow

The last-diten flow to a K Reactor consist.s of thot gortit on of the l.ak tran two or three diesel pumps that diverts to the stmeken K Reactor rother ser. fllowirg to the other $K$ Reactor which has some low-lift pumps in operation. This flow is measured in two manners:

a. Flow tube meter in the crosstie line to the stricken reactor

b. A colibration curve of the bottom of $A$ and $E$ riser pressures (BORP) versus the reactor flow supply through the $A$ and $B$ risers oniy.

The best avallable riser calibration curve for the $k$ Reactors is presented in Figures $l$ and $\hat{c}$, and $i: g$ obuined from the experimental data of three recent if production testes, $\div, 5,6)$ plus a treostial riser presisure curve obtained from a system nydralalis study,(?) 


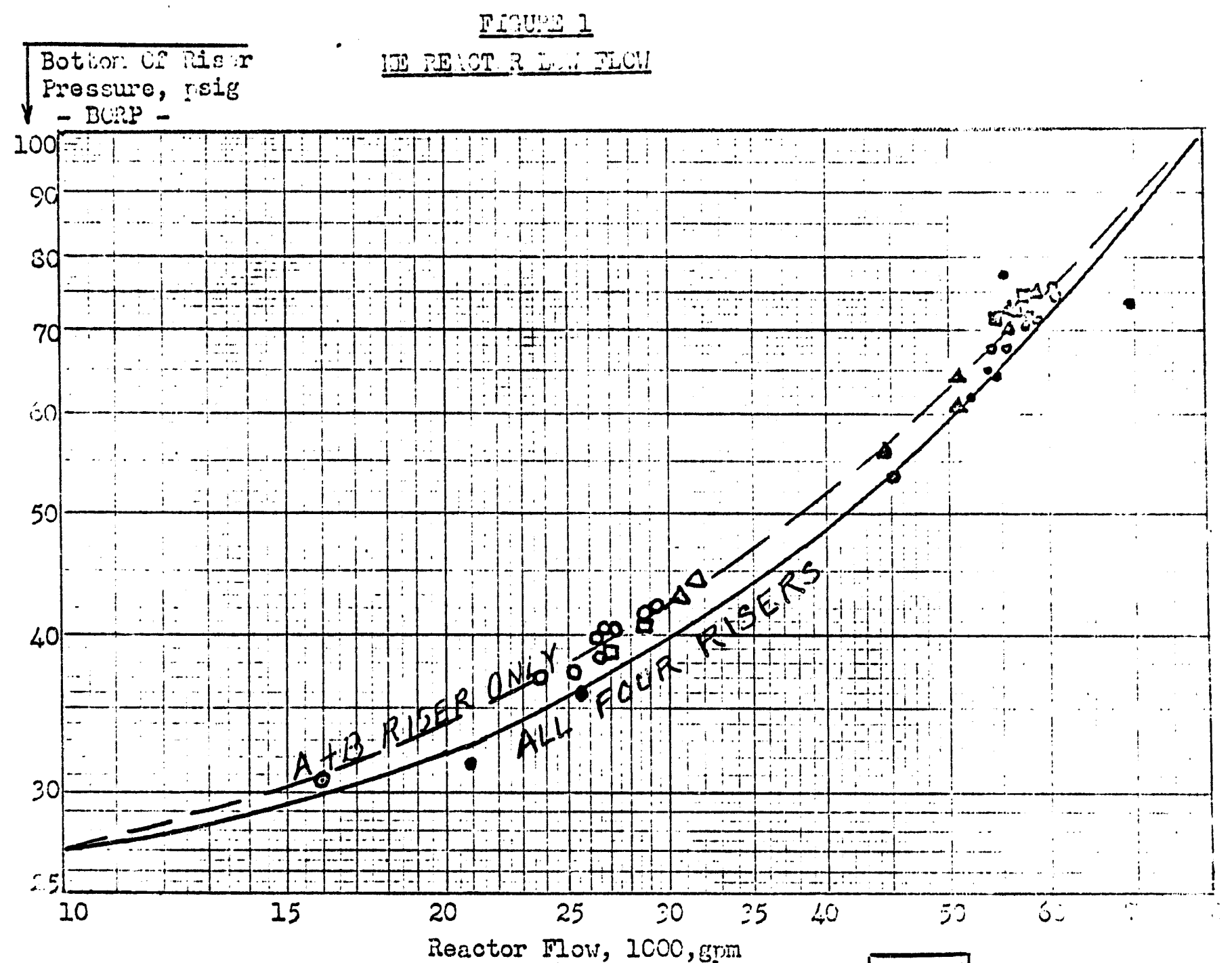

Reactor Flow, 1C00, grm

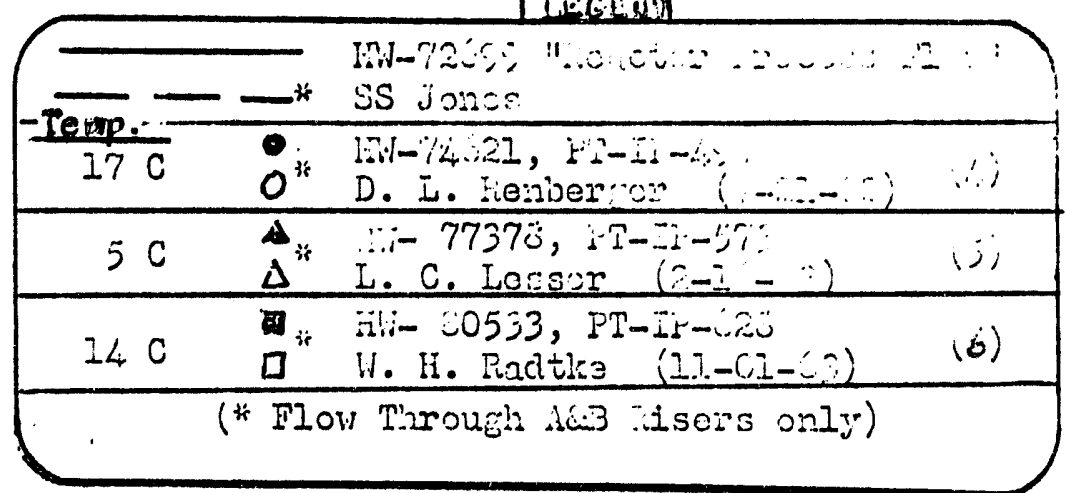




\section{FIGUPE 2}

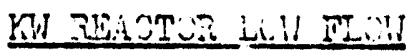

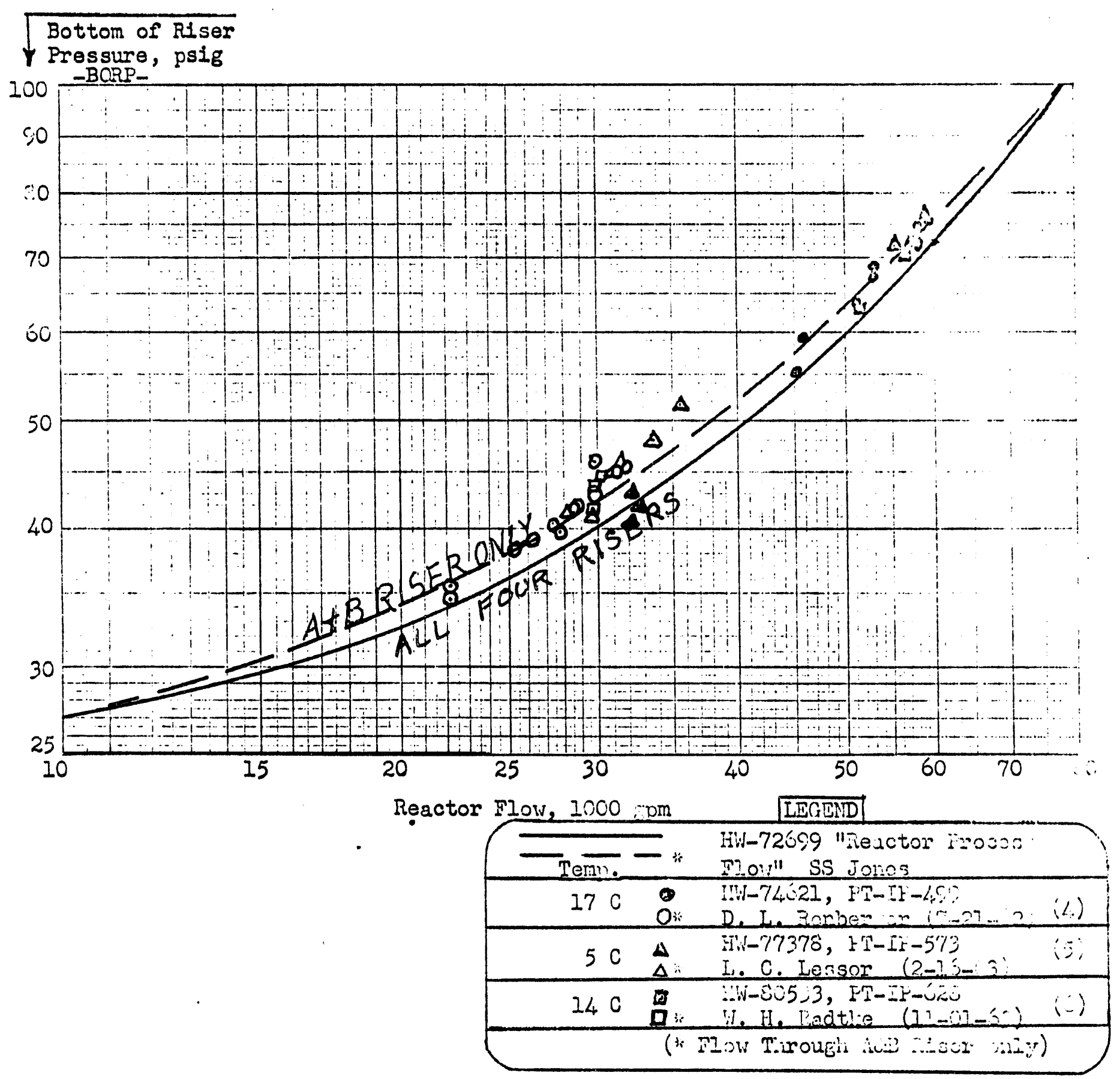


The calibration curve for the crosstie orifices is available from the KReactor process engineer; who, also, should have the most up-to-date reactor riser calibration curve similar to Figures 1 and 2 .

\section{Assured Reactor Flow}

Because of the extreme importance of adequate last-ditch cooling, as noted earlier, a number of factors are applied to this measured last-ditch flow before it can safeig be called assured last-ditch flow,

The general equation to convert from measured to corrected, or assured, reactor flow is:

$$
G_{A}=\frac{F_{S} F_{C} F_{T}}{1+F_{G}} \quad G_{M},
$$

where

$F_{S}=$ the allowance for strainer plugging during an actual emergency,

$\mathrm{F}_{\mathrm{C}}=$ the corrosion allowance which depends upon time since line cleaning or actual emergency flow measurement,

$\mathrm{F}_{\mathrm{T}}$ - a temperature correction factor to allow for the decreased reactor resistance under the elevated effluent temperatures of emergency conditions, and

$1+F_{G}=$ a term to allow for increasing errors in flow measurement at lower and lower flows.

The value and significance of these factors is discussed as follows:

\section{a. Strainer Plugging Factor ( $\mathrm{F}_{\mathrm{S}}$ )}

When detailed last-ditch studies were commenced several years ago, a considerable amount of corrosion products, etc.. were observed during crosstie line flushing prosedures. There is continued evidence of line corrosion and conservatively a strainer plugging factor of $c .96$ is recommended for the possible plugged strainer decrease in diesel pump flow during an emergency event. This represents the coverage of 40 per cent of the strainer area and is considered a conservative but prudent restriction,

There are several important considerations concerning this factor.

1. The severe blocking of only two central zone crossheader screens during an emergency condition could be enough to cause serious fuel burnout and raise serious questions concerning the startup of such a reactor. 
2. There are no strainers in the crosstie line and the emergency flow passes through only the crossheader strainers. Experience has shown that these strainers tend to plug unevenly and therefore individual crossheader flow can be significantly reduced with no apparent change in reactor flow. Therefore, the value of $F_{S}$ for the total reactor is considered to be 1.0 based upon the requirement that individual crossheader flow reduction must not be excessive.

3. There must be a strainer plugging factor for the individual tubes, however; and since this limit occurs near the top of the reactor where the strainer plugging is the least, a factor of 0.98 is recommended.

4. This 0.98 is an arbitrary value subject to change upon adequate evaluation and notification of the experimental values of strainer plugging obtained during the various reactor tests.

b. Iine Corrosion Factor

Considerable crosstie line corrosion was found to have occurred during the system testing upon the completion of Project CGI-844, and the crosstie lines were mechanically cleaned in January, 1963. Their flow was checked at that time and then rechecked in November of 1963. The change in line pressure drop converted to a relative decrease in flow is shown in Figure 3. This was obtalned from a report which discusses the significance of tests performed to evaluate the adequacy of the $\mathrm{K}$ last-ditch cooling system, wherein the test result.s were summarized to obtain an average corrosion effect. (8)

The accurate way to include this corrosion and other factors is to calculate the diesel pump supply pressure curve in terms of BORP. Then, the actual reactor flow will be at the intersection of this curve with the reactor demand curve shown in Figures 1 and 2 . In view of the low accuracy of the experimental data, however, the considerable additional work involved in this more accurate procedure is not warranted.

c . Temperature Factor $\left(F_{T}\right)$

Increasing the coolant temperature increases the flow rate. The magnitude of this effect is shown in Figure 4, where the relative flow factor is shown as a function of the inlet coolant temperature. This is based xpon five general conclusions.

1. The average coolant temperature in going through the reactor during emergency conditions ( $90 \mathrm{C}$ bulk outlet) is very close to $55 \mathrm{C}$.

2. Between test and emergency conditions there would be an increase in reactor flow because of the increase in this average reactor temperatures from 10 to $25 \mathrm{C}$ up to $55 \mathrm{C}$. 


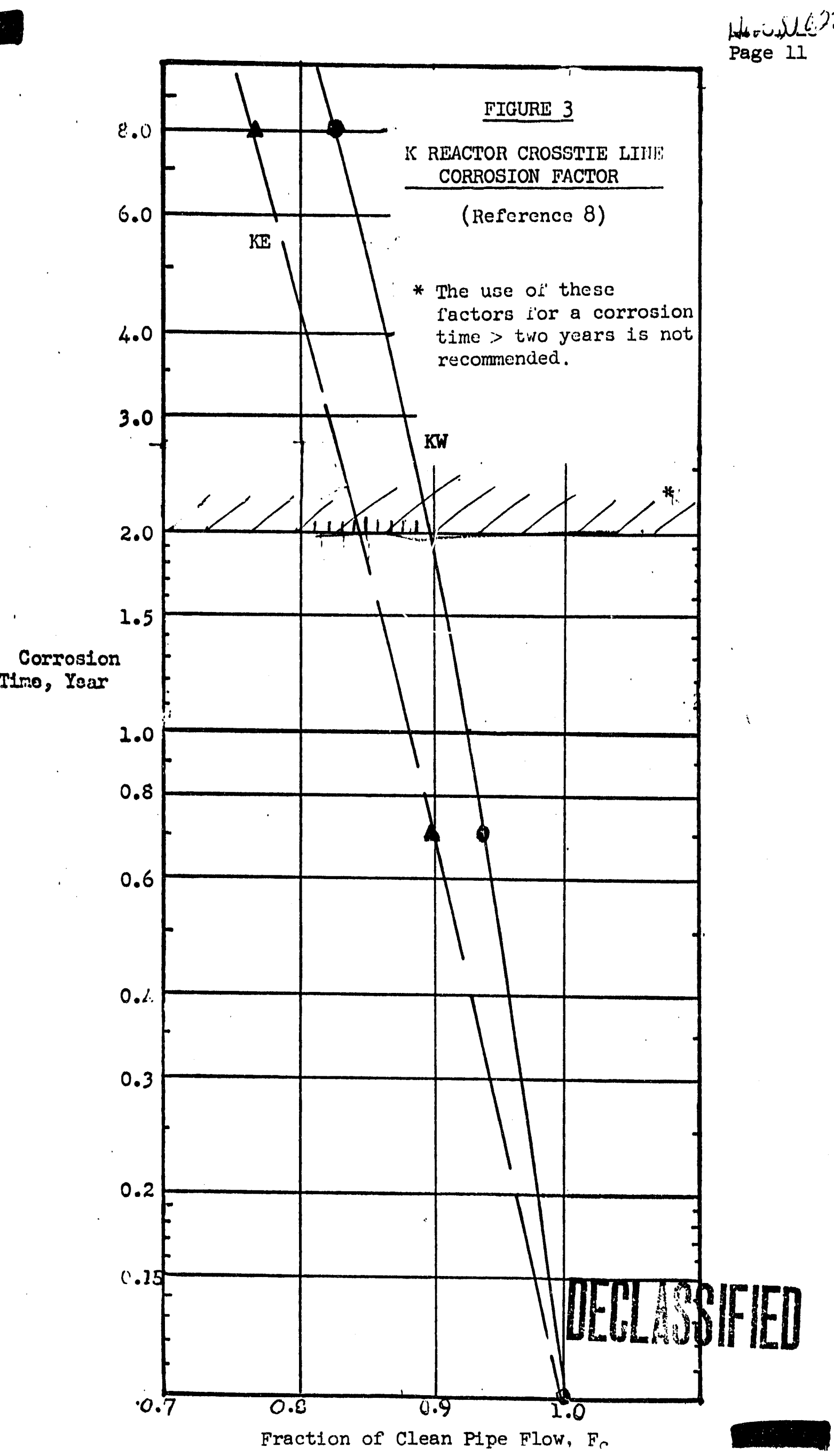


3. The effect of a coolant temperature change upon the line frictional pressure drop is given by the expression:

$$
\Delta p_{f_{T}}=F_{T}^{*} . \Delta p_{f_{55}},
$$

where $\Delta \mathrm{p}_{\mathrm{f}_{\mathrm{T}}}=$ the line pressure drop at $\mathrm{T}{ }^{\circ} \mathrm{C}$,

$\Delta \mathrm{p}_{55}=$ the line pressure drop at $55 \mathrm{C}$, and

$$
\begin{aligned}
\mathrm{F}_{\mathrm{T}}^{*}= & \text { the fractional increase in line pressure drop } \\
& \text { as the coolant temperature is decreased from } \\
& 55 \mathrm{C} .
\end{aligned}
$$

4. Approximately two-thirds of the flow resistance occurs in the crosstie line with the balance in the reactor. Thus, to determine the effect of reactor emergency temperatures upon the measured cold flow, we can only consider the reactor part of the system. The fractional flow increase for this effect is given as:

$$
F_{T}=\left(\frac{\Delta p_{f_{c}}+F_{T}^{*} \Delta p_{f_{R}}}{\Delta p_{f_{c}}+\Delta p_{f_{R}}}\right)^{.54},
$$

where $F_{T}=$ fractional increase in reactor flow between test and emergency conditions ( $i, \epsilon ., 55 \mathrm{C}$ ),

$$
\begin{aligned}
& \Delta p_{f_{c}}=\text { crosstie pressure drop }-p s i \text {, and } \\
& \Delta p_{f_{R}}=\text { reactor pressure drop }-p s i \text {. }
\end{aligned}
$$

5. To compare one measured flow condition with another measured flow at a different temperature, use is made of equation $(2)$ since the whole system is at the given temperature. Thus, to determine the expected measured flow at $25 \mathrm{C}$ from a value measured at $5 \mathrm{C}$, we use the relationship:

$$
G_{2.5}=\left(\frac{F_{5}^{*}}{F_{25}^{*}}\right)^{.54} G_{5}=1.08 G_{5} \text {, }
$$

and velies of this exponertial pressure drop correction ratio are presented as $F_{T}^{\prime}$ in Figure ${ }_{+}$. Here $F_{T}^{\prime}$ is based upon a $20 \mathrm{C}$ coolant temperature. Applying this to the above problem gives:

$$
G_{25}=\frac{F_{25}^{\prime} G_{5}}{F_{5}^{\prime}}=1.08 G_{5} \text {. }
$$


FRACTIONAL PRESSURE DROP CHANGE $F_{T}^{*}$

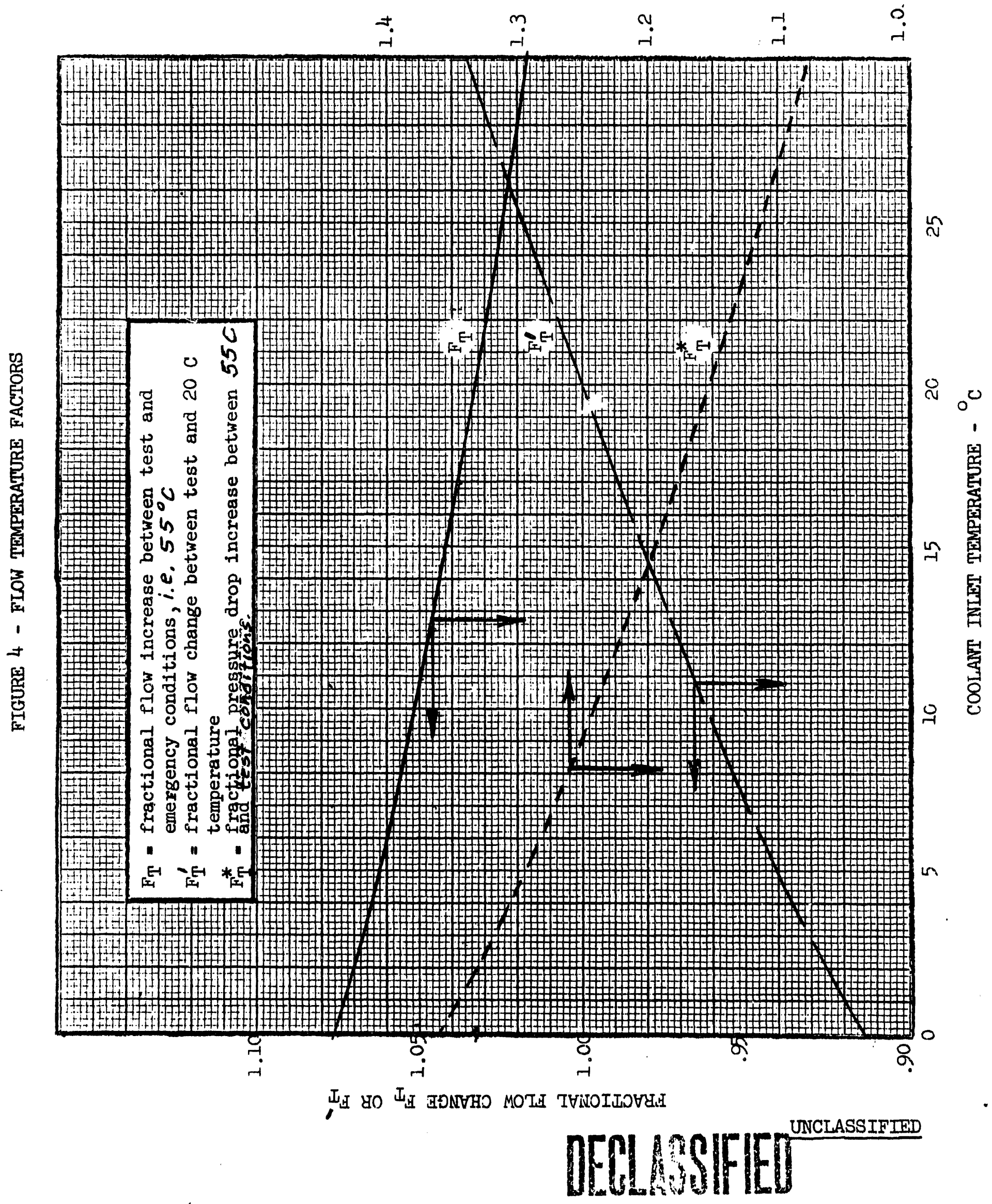


d. Low Flow Error Factor $\left(1+F_{G}\right)$

It can be shown that the flow error is related to the various errors in pressure measurement, by the expression

$$
\frac{\Delta G}{G}=0.54 \frac{\Delta P_{T}+\Delta P_{D}}{P_{T}-P_{D}} ;
$$

where $\frac{\Delta G}{G}$ - the fractional error in the reactor flow,

$$
\begin{aligned}
& P_{T}=\text { reactor riser pressure - psig, and } \\
& P_{D}=\text { reactor top of downcomer pressure - psig. }
\end{aligned}
$$

Assuming pressure errors of $1 . \bar{j}$ psi riser pressure and 1 psi top of down. comer pressure, this latter made of barometric pressure variations, and actual pressure errors, we obtain for 10,000 gpm fllow

$$
\frac{\Delta G}{G}=0.54\left(\frac{1.5+1}{19-0}\right)=0.072
$$

This and corresponding error values are shown as the higher curre in Figure 5.

As noted in a recent report ${ }^{(8)}$, a survey of the experimental results of measured $K$-Reactor emergency flow does not indicate high accuracy. Whether this is because of pressure errors, oriflce flow meter errors, or pump discharge errors is not known. But the scatter in the experimental resuits indicates a variety of errors, without any definite trend or evident source. and the higher value of $1+F_{G}$ should be used. This should apply unti I more consistent experimental results warrant an evaluation of lower errors in emergency flow measurement. When this is done, the lower error curve should not be used for test data more than two years old or for flow changes without test data in excess of ten per cent.

With these various factors determined, we can then calculate an assured reactor emergency flow and determine the critical time of emergency floiv takeover, as noted in the following section.

4. Critical Flow Time and Heat Extraction Factor

a. Critical Flow and Time

The basic criterion for this condition is the point of maximum bulk outlet temperature during the period of diesel-pump takeover from the flow decay provided by the pump flywheels. Because of the hazard involved, 
HTV-8IO2B

Page is

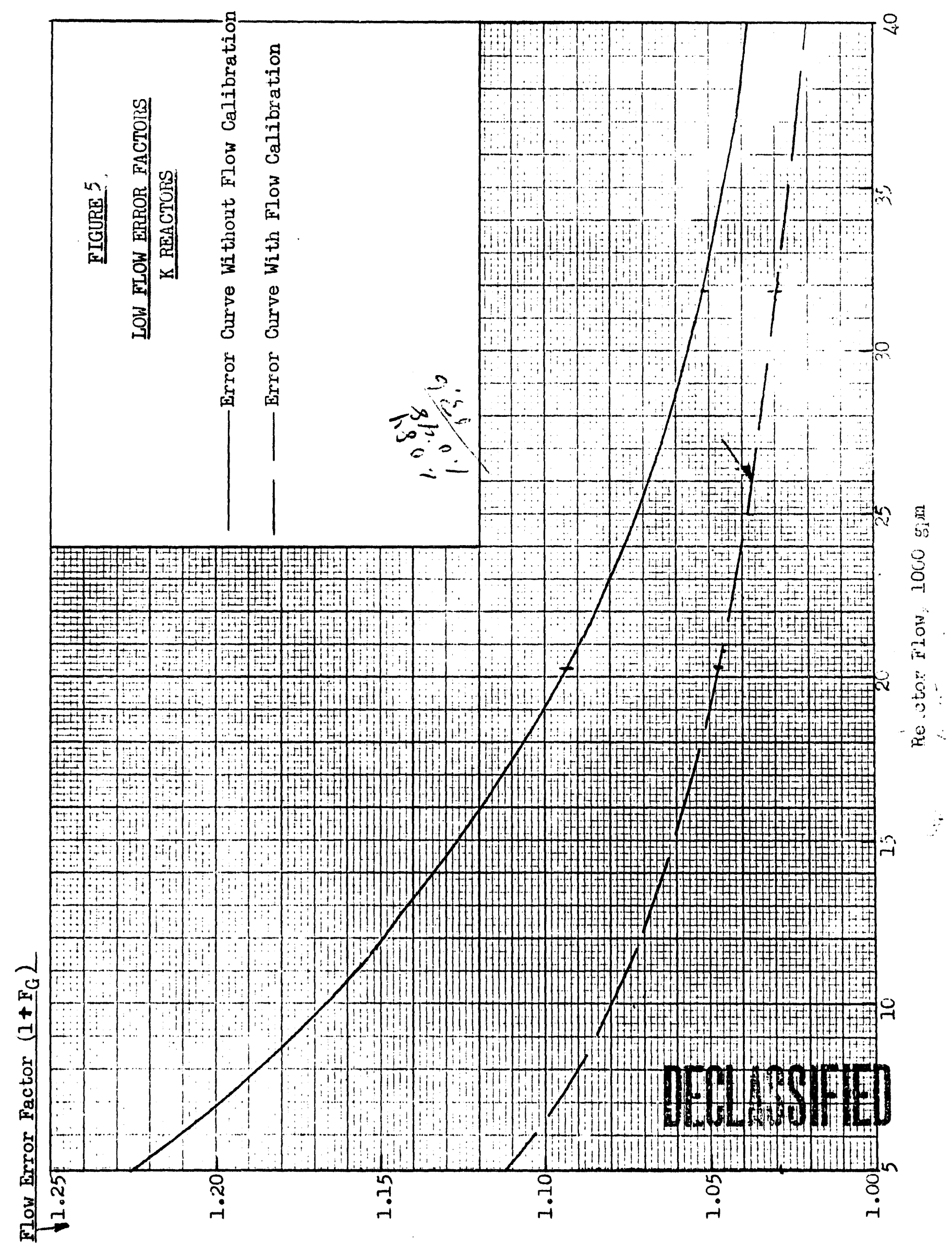


this condition is not measured experimentally. However, it can be closely approximated by combining the reactor heat extraction requirements with the experimental flow decay measurements summarized in earlier reports. $(t, 5)$ This determination is shown in Figure 6 . It occurs just at the point where stable last-ditch flow is achieved.

Because of the reactor shutdown requirements and other difficulties involved in the actual measurement of this critical diesel-pump flow to the reactors, it is often desirable to measure a steady-state diesel-pump flow to one or both reactors. It is even planned to measure changes in dieselpump flow through a fixed drain line on an intermittent basis. In this case, this flow must be translated to a reactor flow and then to a critical flow time.

Studies are in progress on the comparison of theoretical and actual reactor flywheel flow decay. Unt1l these are completed, an approximate procedure is presented in the specification. This uses the basi: flywheel flow decey equation and experimentally determines the lumped parameter $\alpha$ that incide:: the flywheel inertia, speed, and other flow decay effects.

The basis pump flywheel decay curve can be represented by the simplified expression:

$$
f_{G}=\frac{G_{M}}{G_{M_{0}}}=\frac{1}{1+\alpha \tau} .
$$

Where $G_{M}=$ flywheel decay flow seconds after power loss - $1000 \mathrm{gpm}$,

$$
\begin{aligned}
& G_{M_{0}}=\text { original pumping flow }-1000 \mathrm{gpm}_{9} \\
& \tau=\text { time after loss of pumps - sec., } \\
& \alpha=\text { over-all flywheel inertia and system constant, and } \\
& f_{G}=\text { fraction of original flow. }
\end{aligned}
$$

This equation was applied to the six-pump flywheei decay, Test A-1 of reference (5), and an average value of .049 was obtained for $\propto$.

The typical reactor flow and power-level decay following the loss of pumpitre power and a reactor scram are depicted in Figure 6 . At the same time, she corresponding bulk outlet temperatures are shown for various val ies of $1 n$ iet coolant temperature. The significant condition in this rigure is $t_{6} \cdot t$ the seak bulk outlet temperatures are obtained just at the point of achie ing stable flow, i.e., where the system taking over from the pump flywheel decay has just barely completed the process and stable secondary or last-ditch flow is obtained.

To change from a known to an unknown critical flow-time condition, the following procedure is applied. From the known test conditions, we can determine: 


\section{FIGURE 6}

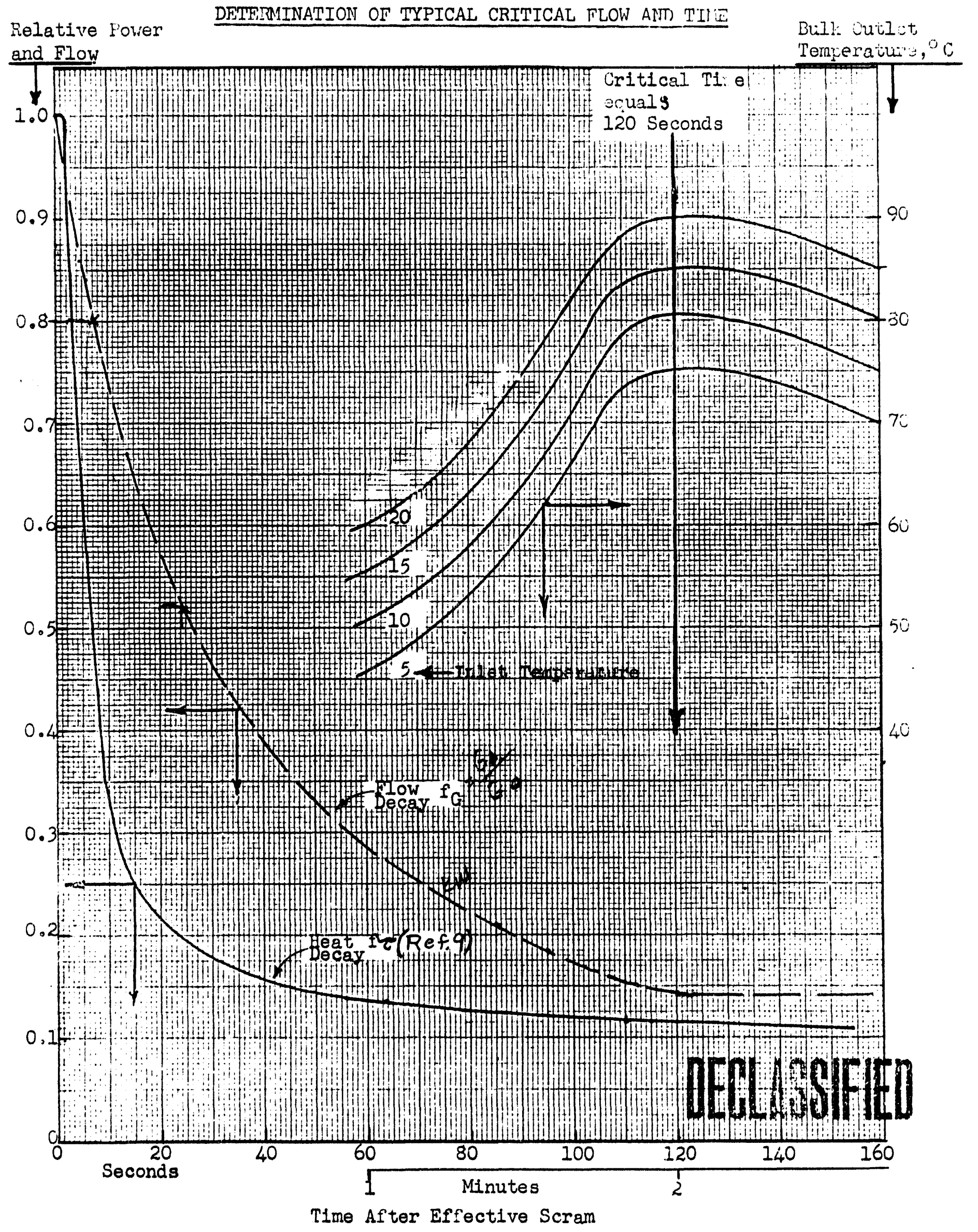


1. $f_{G}=$ the fraction of original full-level flow at the point of stable secondary or last-ditch flow during the pump flywheel decay,

2. $\tau_{c_{0}}$. the time that this stable flow is just achieved - seconds, and $\begin{aligned} & 3 . \tau_{0}=\text { the theoretical time that this flow would be achleved from } \\ & \text { the relationship: }\end{aligned}$

$$
\tau_{0} \cdot \frac{1-f_{G_{0}}}{\alpha f_{G_{0}}}=\frac{1-f_{G_{a}}}{(.049) f_{G_{0}}} \text { *. }
$$

This implies, and correctly so, that a deviation exists between the theory and experiment. This is small and using the theory to change the experimental results on a ratio basis should provide a fairly accurate new value of critical flow time. Thus, for the case of a new emergency flow, we first determine**:

$$
\begin{aligned}
& f_{G_{X}}=\text { the ratio of the stable emergency flow to the full level } \\
& \text { flow. }
\end{aligned}
$$

Then we calculate the theoretical critical flow time according to the equation.

$$
J_{x}=\frac{1-f_{1 x x}}{(.049) f_{G_{x}}},
$$

and finally we determine an empirical value of the expected critical flow time for the new conditions according to the ratio expression

$$
\mathcal{T}_{c_{x}}=\mathcal{T}_{c_{0}}\left(\frac{\mathcal{J}_{x}}{\mathcal{J}_{0}}\right) \text {. }
$$
Where $\mathcal{F}_{c_{x}}$ - the actual critical flow time for the condition of the

$$
\mathcal{F}_{\mathrm{x}}=\text { the theoretical critical flow time, and }
$$

subscripts 0 and $x$ refer to the test flow decay time and the unknown flow decay time, respectively.

* Where $\alpha$ has been determined from one decay test, reference (5) Test A-1, and is subject to change upon futur testing.

* A simple approaci to this problem was developed by W. H. Radtke, namely that a linear plot of $f_{G}$ vs. $f_{\tau}$ is obtained. This bypasses the determination of the r.itical tine and should apply for all cases where significant changes have not been made in reactor flow or primary pumping characteristics. The linear curve is presentea in Fisure 7. 


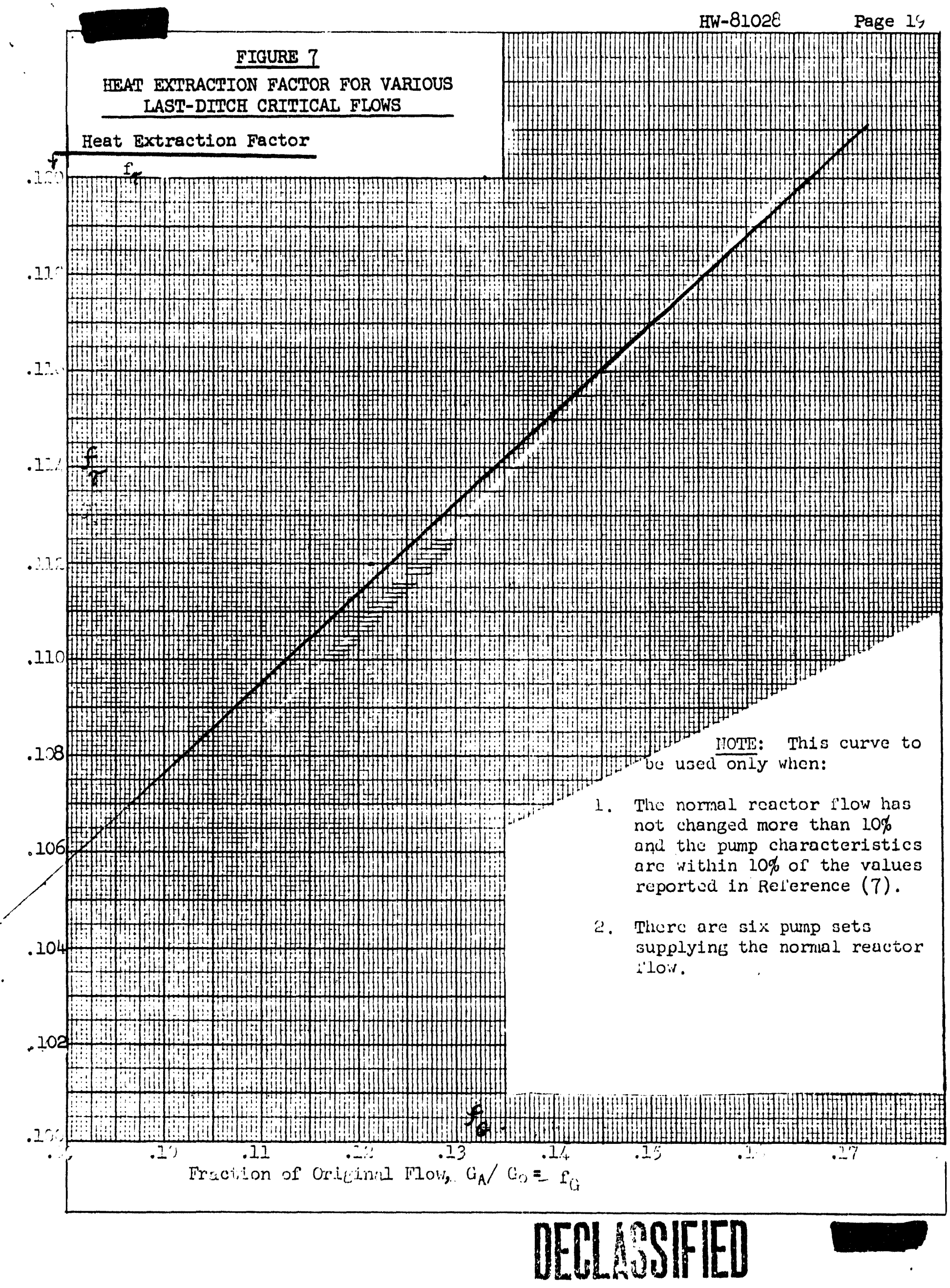


HW-8102R

Page 20

b. Heat Extraction Requil rements after Emergency Scram $(f \tau)$

The amount of coolant required is a direct function of the amount of heat to be extracted and this in turn depends upon the temperature rise of the coolant in passing through the reactor. In a recent test, the effect of raising the coolant outlet temperature was investigated, on the basis of this test, a modified heat output curve was obtained. (9) For convenience. this is presented in Figure 8 as it applies to the $K$ Reactors.

5. Maximum Reactor Power Level for Adequate Last-Ditch Cooling

a. Outlet Temperature Iimit

1) Reactor Emergency Bulk Temperature Limit

During emergency flow, bulk bolling may occur in the reactor effluent, system at the top of the downcomer at temperatures as low as $98 \mathrm{C}$. At these low emergency flows, there is very little pressure driving force and bulk boiling with the accompanying pressurization could readily lead to fuel burnout and serious reactor damage. Therefore, the maximum allowable bulk outlet temperature at 20 or more seconds follawing a reactor scram is essudulshed as $90 \mathrm{C}$. This is presented in Technical Bases Dr.

\section{2) Reactor Emergency Tube Outlet Temperature Limit}

Laboratory studies of Individual tubes at the low pressures associated with emergency flow conditions have indicated that fuel burnout can occur at shutdown power level conditions and that cooling by boiling cannot be depended upon to ensure adequate fuel cooling. (11,12) Therefore, it is important that tube outlet temperatures be limited to values below the saturation point. Conservatively, a limit has been established of $5 \mathrm{C}$ below the corresponding rear crossheader saturation temperature. This saturation temperature, and thus the tube outiet temperature, increases as we go down the reactor, by as much as $10 \mathrm{C}$. Thus, from these considerations, it is best to peak the reactor power level at the bottom rather than the top of the unit.

The tube outlet emergency temperature limit, $T_{L}$, (equal to crossheader saturation temperature minus $5 \mathrm{C}$ ) depends upon the crossheader presiire This is determined as the sum of the static and friction pressures from the top of the downcomer down to the first headers with naximum pciwared tubes. It is assumed that the top of the downcomer is at atmospheric pressure. This value of $5^{\circ}$ allows for a cumulative error of four feet in the location of the highest temperature crossheader, one foot in the level of water in the downcomer approach section, 1 psi error in the frictional pressure drop in this section of the effluent system, and 0.4 psi depression of the top of downcomer pressure below 14.7 psia. This latter effect being a combination of small suction pressure effects created by the downcomer system, and barometric changes. Based upon these assumptions, the limiting tube out let temperatures at 20 seconds or more after a reactor loss of pumping power are shown in Figure 9. 
Fraction of Original

Heat Extraction, $\mathrm{f}_{\boldsymbol{\tau}}$

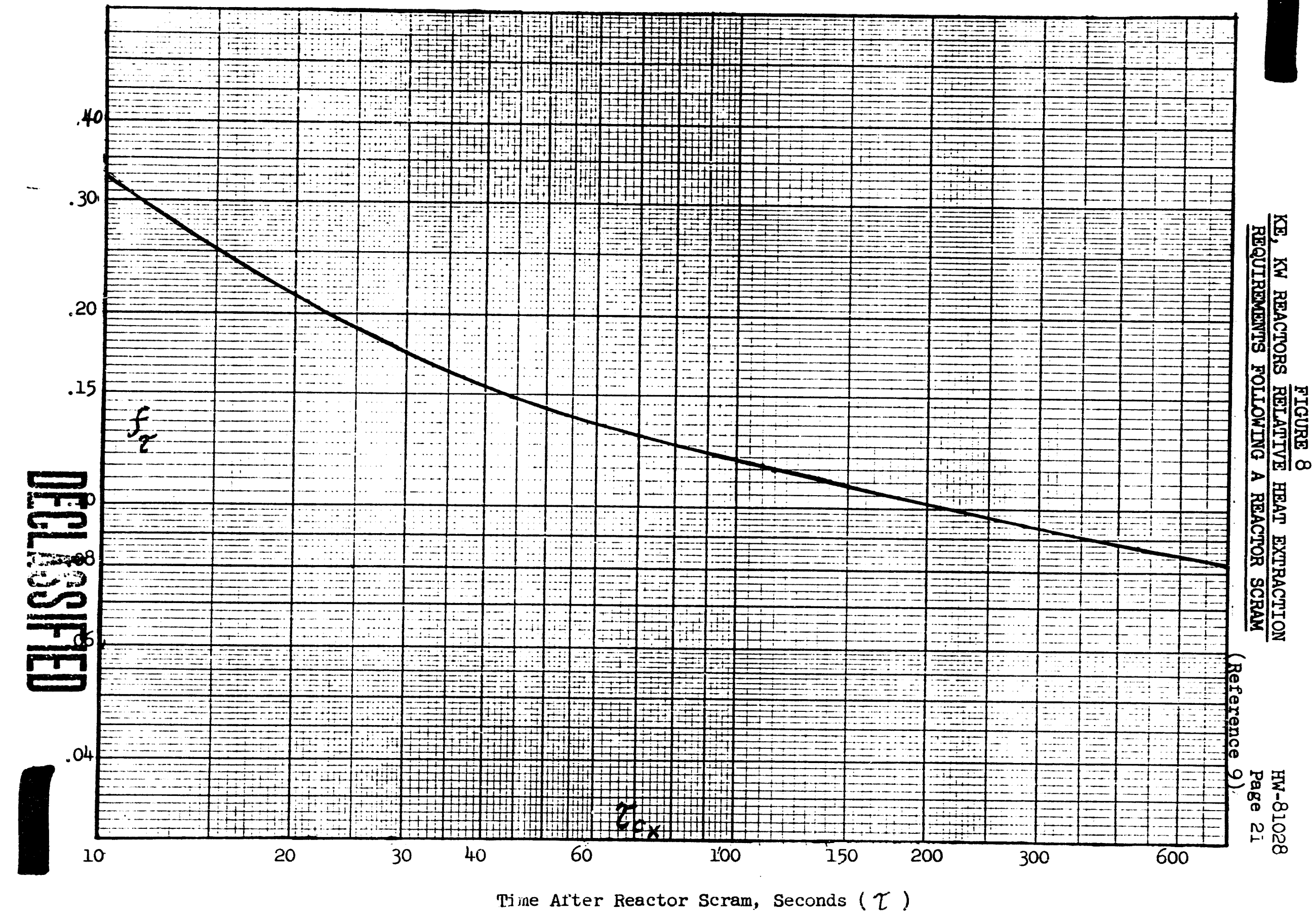


Tube Outlet

Temperature

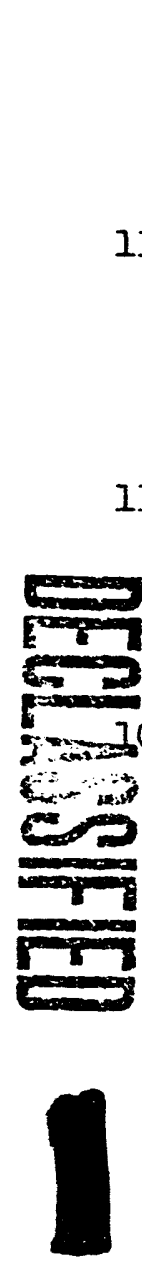

$\mathrm{T}_{\mathrm{L}},{ }^{\circ} \mathrm{C}$
FIGURE 9

K REACTORS EMERGENCY FLOW TUBE OUTLET TERTPERAIUTRE LIIIT

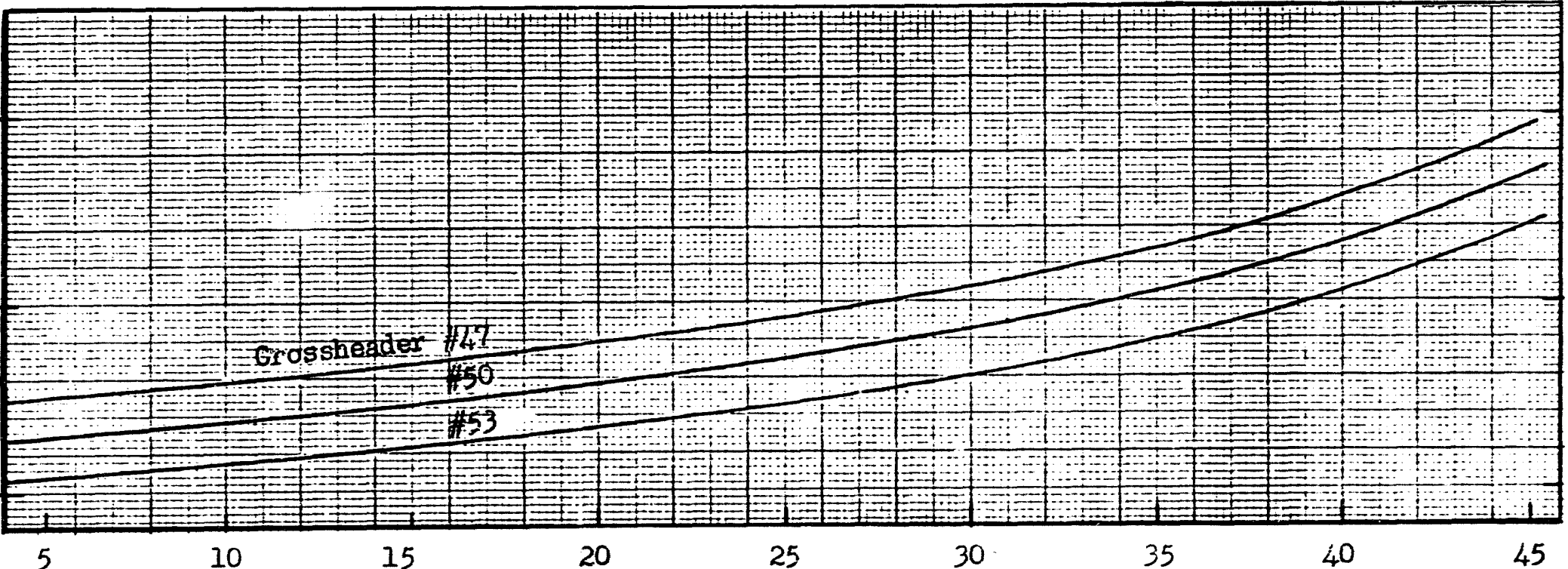

Reactor Flow, 1000 g!: 


\section{b. Power Level Adequacy}

1) Bulk Temperature Limit

The basic equation for the determination of the maximum reactor power level, for which adequate last-ditch cooling is assured, is given as:

$$
P=\frac{0.264}{f_{\tau}} \quad G_{A}\left(90-T_{i_{c}}\right) ;
$$

where $P=$ the maximum power level for cooling adequacy based upon the bulk outlet conditions - MW,

$G_{A}=$ assured diesel-pump flow to the stricken $\mathrm{K}$ Reactor - $1000 \mathrm{gpm}$, $\mathrm{T}_{\mathrm{i}_{\mathrm{C}}}$ - the crosstie line temperature $-{ }^{\circ} \mathrm{C},{ }^{*}$ and

$f_{\tau}$. the heat extraction decay factor from Figure 7 or 8 at the time of diesel-pump critical flow.

2) Tube Outlet Temperature Limit

As noted earlier, we have both a bulk and a tube temperature limit. The latter is given by the relationship:

$$
P_{t}=\frac{0.264}{f_{\tau}} F_{S} G_{A}\left(T_{L}-T_{I_{c}}\right) F_{\varepsilon} ;
$$

where $P_{t}=$ the maximum power level for cooling adequacy based upon tube outlet temperature limits (i.e., crossheader saturation temperature) - Mw,

$F_{S}=$ crossheader strainer plugging factor assumed $=.98$,

$G_{A}$ - the assured diesel-pump critical flow in $1000 \mathrm{gpm}$,

$T_{L}=$ the tube outlet temperature limit $-{ }^{\circ} \mathrm{C}$ (Values of this limit for the $K$ Reactors are presented in Figure 9.?,

$T_{I_{C}}=$ the crosstie coolant temperature $-{ }^{\circ} \mathrm{C}$, ${ }^{F_{E}}=\begin{aligned} & \text { the reactor flattening efficiency }=.84 \text { as of January, } \\ & 1964 \text {, and }\end{aligned}$

$f_{\tau}=$ the heat extraction decay factor from Figure 7 or 8 at the time of critical diesel-pump takeover.

* This is now arbitrarily assumed to be $5 \mathrm{C}$ above process water inlet tempera- ture. 
With the power level determined for both bulk and the tube temperature limits, the lower of the two levels should be used. above $5-10 \mathrm{C}$, the bulk temneratuma jimit is alwavs contmo fing and often it is controlling over the whole range of coolant inlet temnerscures:

6. Required Last-Ditch Cooling for a Desired Reactor Power Level

In general, the foregoing process is used in reverse. There are however several important points to be noted. These will be discussed, briefly summarizing the actual process of the determination of flow requirements.

\section{a. Required Assured Last-Ditch Flow}

This is readily obtained by transposing equations (1), (8), and (9).

Iimiting Bulk Outlet Temperature

$$
\begin{aligned}
& G_{A_{B}}=\frac{f_{\tau} P_{0}}{0.264\left(90-T_{i_{C}}\right)}, \\
& G_{M_{B}}=\frac{\left(1+F_{G}\right) G_{A_{B}}}{F_{T}} ;
\end{aligned}
$$

where $G_{M_{B}}$ is the value of diesel-pump flow (to the stricken reactor) that should be measured to assure adequate bulk cooling at the desired reactor power l.evel.

Limiting Tube outlet Temperature

$$
\begin{aligned}
& G_{A_{t}}=\frac{f_{\tau} P_{0}}{0.264\left(T_{L}-T_{i_{c}}\right) F_{\varepsilon} F_{S}}, \\
& G_{M_{t}}=\frac{\left(1+F_{G}\right) G_{A_{t}} ;}{F_{T}}
\end{aligned}
$$

where $C_{M}$ is the value of diesel-pump flow to the stricken reactor that should bt measured to assure adequate process tube cooling at the dssired reactor power level. The important process here is to use both equations, $i, e, 10 a$ and $l a$ or $11 a$ and $l b$ in determining the filow.

7. Corrosion and Pumping Effects

The current crosstie pipe line corrosion conditions are shown in Figure 3 and explained in detail in reference (8). This is a situation that will require

* The strainer piugging factor $\mathrm{F}_{\mathrm{S}}$ is arbitrarily placed in equation (1la) rather than (1) to yield a constant ratio of assured to measured flow for both bulk and tube considerations. 
close following and is subject to considerable change as sters are tilsen t, reduce or eliminate the problem. It will be important to yodets tre conve: : factors presented in Figure 3 as chenges are made and adiitisra? tert resiit: obtained.

a. Effect of Pumping Conditions at Other Reactor

The emergency flow diesel pumps provide flow and pressure to the junction of the diesel pump discharge line with the high pressure crosstie. From here the flow is distributed to the KE and KW Reactors according to their riser back-pressure and their crosstie hydraulic resjstance. The croetor the secondary system flow to the unstricken reactor, the greater the diversion of emergency flow to the stricken unit. In the use of this anelysis, however, it is only important to know the stricken reactor's critical flow. The same method for the determination of last-ditch cooling adequacy should be used irrespective of the number of pum in ogeration at the aiding ractor. This number wit, if crisse, influens: the measured flow value $\left(\mathrm{G}_{\mathrm{M}}\right)$ to be usec for the cetom: $\%$ ditch cooling adequacy.

This completes the outline of a method for determining the cooling adequary of the K-Reactor last-ditch cooling system. The method can be used with mi nor modifications for determining the cooling adequacy of the secondary copling system. In general, however, the capacity of this systern is so mucit in excess of its requirements that the various flow correction tactors $\mathrm{du}$ a di

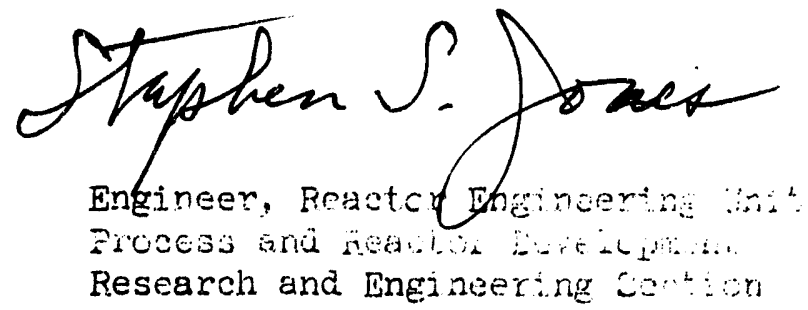

SS Jones: nmd

\section{A.CKNOWLEDC:MENT}

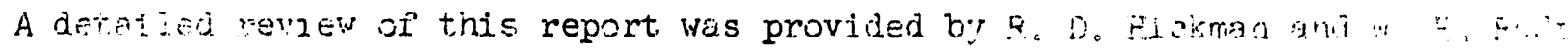

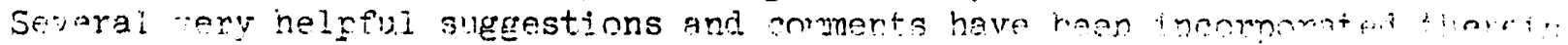




\section{REFERENCES}

(1) Trumble, R. E. Performance Criteria for the Hanford Production Reactors, HW-66929. September 1, 1960 .

(2) Van Wormer, F.W. Performance Criteria for Irradiation Processine Departmert: Production Reactors, Fil-79695. November 20, 1963.

(3) Staff of Irradiation Processing Department. Hazards Summary Report - Voiume $\overline{-}$ Description of the 100-KE and the 100-KW Production Reactor Plants, Fil-7to95 VOI? Apr11 22, 1963. pp. 46-49. (SECRET).

(4) Renberger, D. L. Numerical Results of PT-IP-499-AM, Test of the 182-K Diesel Pumps at $\mathrm{KE}$ and $\mathrm{K}$, $\mathrm{HW}-74621$. August 21, 1962. (SECRET).

(5) Lessor, L. C. Pressure and Flow Data PT-IP-573-I, 100-K Flow Tests, HW-7?378. April 24, 1963. (SECRET).

(6) Radtke, W. H. Results of Production Test IP-628-I, Crosstie Flow Test and Flushing Calibrations, HW-80533. January 23, 1964. (SECRET).

(7) Jones, S. S., J. E. Morrissey, and J. L. Manuel. Reactor Process Flow Technical Data, HW-72699. February 15, 1962.

(8) Jones, S. S. Technical Note on the Results of Production Test IP-628-AI, Crosstie Flow Test and Flushing Calibrations, Hiv-81027. February 27, 1964

(9) Jones, S. S. and J. L. Manuel, Numerical Results of PT-IP-338-A SUPP A, DR-

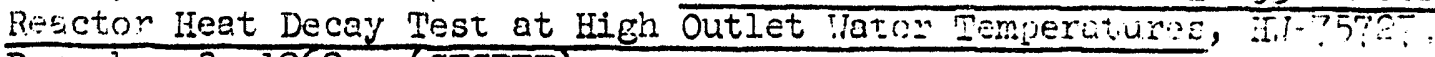
December 3, 1962. (SECRET).

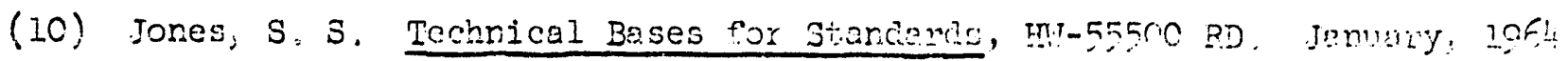

(11) Waters, E. D. and D. E. Fitzsimmons. Pressure Required to overcome Thibe Eir: out During Transient Corditions, FN-66274. Alugust 5, 1960. (SECRET).

(12) Carlson, P. A, and S. S. Jones. Potentfal for Frocess Tuice Burbout Dr...nn: Transient Conditions, HW-61760. April 2?, 1960. IECFEI: 

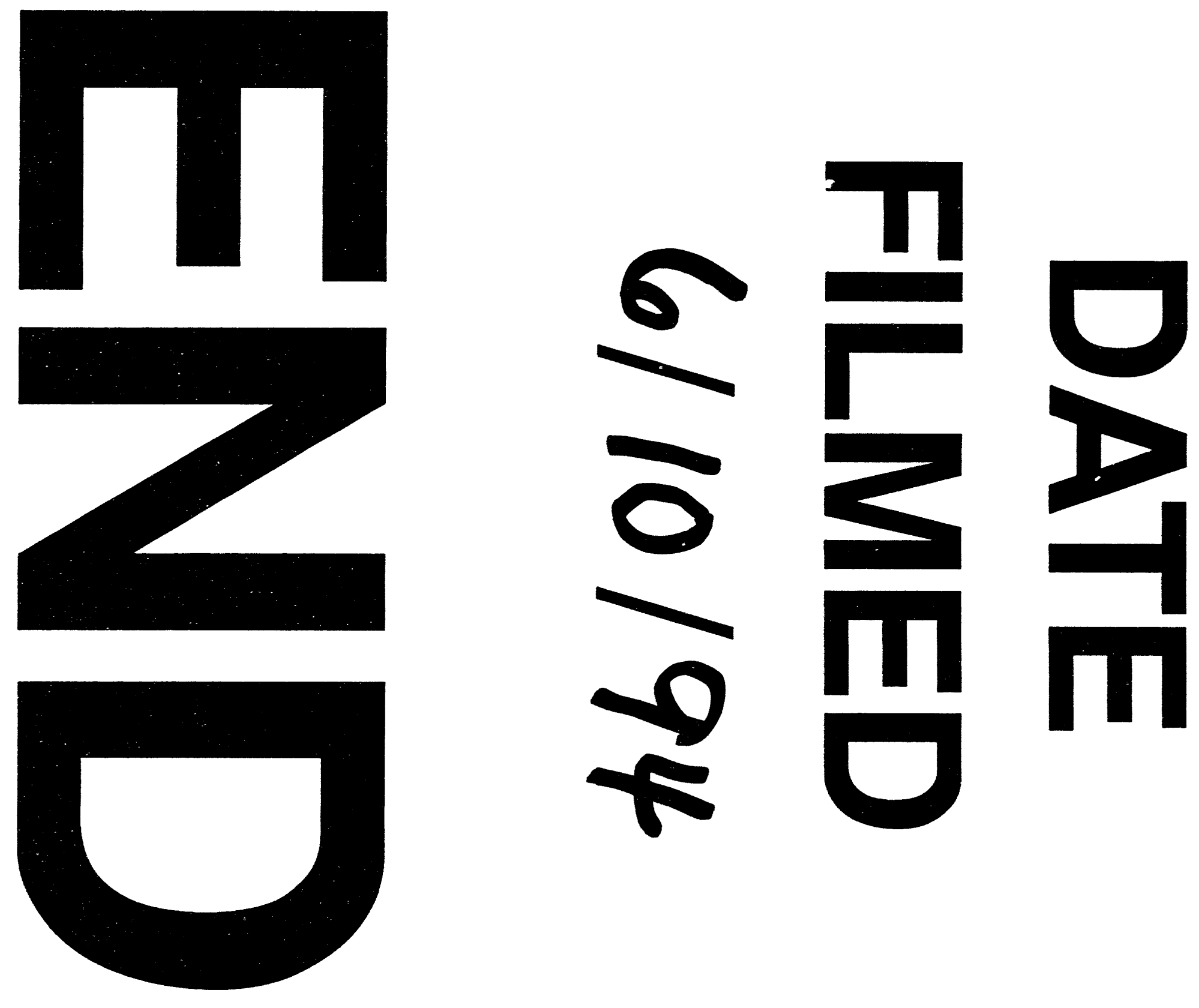
